\title{
Bokrecension
}

\section{Att sjunga i kör}

Pirjo Nenola. 2019. Kuorolaulaminen Suomessa. Etnografinen tutkimus

performanssista. Jyu dissertations 81. Jyväskylä: Jyväskylän yliopisto. 249

sivua. http://urn.fi/URN:ISBN:978-951-39-7762-7

\section{Lena Marander-Eklund}

\begin{abstract}
$A^{t}$ tt som inbiten körsångare läsa en etnologisk text om körsång, Pirjo Nenolas avhandling Kuorolaulaminen Suomessa (2019), är spännande. Min förhandsinställning var aningen kluven: kommer jag att känna igen mig i analysen eller innebär min position som insider att ämnet för avhandlingen känns för bekant. Jag undrade också över om jag kommer att läsa avhandlingen extra kritiskt eftersom temat är bekant för mig. Det visade sig att min läsning karaktäriserades av igenkännandets glädje, men också av viss förvåning som i sig naturligtvis inte behöver vara negativ. Även Nenola själv är "körnative", något som hon problematiserar och ser som en fördel $i$ sammanhanget.
\end{abstract}

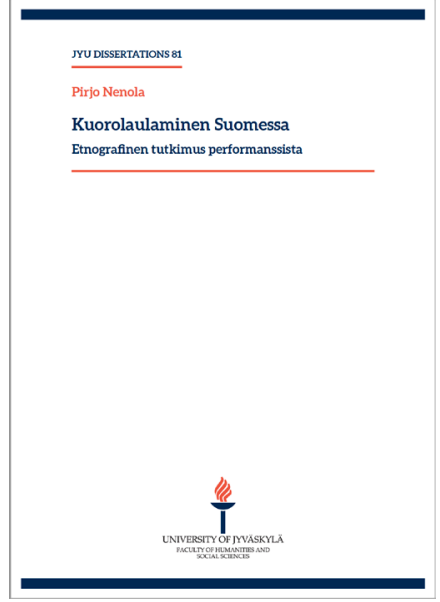

\section{Etnologisk forskning om körsång}

Avhandlingen är skriven i ämnet etnologi och inte i musikvetenskap. Det innebär i detta fall att själva musiken är relativt frånvarande i avhandlingen med vissa undantag, till exempel då fosterländskhet diskuteras. Läsaren får veta ganska lite om repertoarval och fokusering på olika musikstilar och klangideal i körverksamheten. Fokus ligger istället på körsång som performans, som ett framförande. Nenolas huvudsakliga frågeställning formulerar hon ungefär enligt följande: att studera körsjungandet i Finland ur ett performansteoretiskt perspektiv med utgångspunkt i etnografisk analys. Fokus ligger på körsångarnas verksamhet under körövningarna, körframträdanden och under deras gemensamma fritid. Hon analyserar händelsernas rituella natur, traditioner, symboliska system och sociala roller samt deras kontext. Performansen ser Nenola som en lins, genom vilken man kan studera hur beskrivningar av kören som institution, samhället och tiden skapas. Centrala frågor är också vilka upplevelser som körsångarna uppfattar som viktiga och hur de återskapar en körkultur.

Problemformuleringen är medvetet öppet hållen för att på så sätt skapa ett rikligt etnografiskt material om ett, enligt författaren, ur etnologiskt perspektiv outforskat område. Det här 
ser jag både som avhandlingens styrka och dess svaghet. Styrkan består i att avhandlingen ger en inblick i hur körsångarens vardag ser ut med övningar och framträdanden. I dessa passager finns stor igenkänning - just så där går det till. Exempel på detta är hur nya sångare tas emot i kören och placeras mellan erfarna sångare för att på så sätt få en lättare start, hur man på en körövning glömmer allt annat och går helt in i sjungandet, eller hur man kan bli småirriterad på medsångare som förlitar sig på sin körkompis istället för att själv ta ansvar för sin stämma. Det är också frågan om att sjungandet i kör ger en stark känsla av strävan mot gemensamma mål och gemenskap. Men det finns också gånger jag inte känner igen mig. Detta blir tydligt exempelvis då Nenolas informanter inte alls upplever att köradministration är krävande och då hon ger en historisk exposé där jag saknar studentkörernas (både på finskt och finlandssvenskt håll) speciella position som föregångare i körvärlden samt damkörernas musikaliska framgångar på senare tid. Samtidigt som avhandlingen känns bekant - vilket i sig visar att hon nått sitt mål - upplever jag att den ger en relativt homogen och för positiv bild av körfältet.

\section{Vad är en kör?}

Nenola definierar en kör som en grupp som sjunger en- eller flerstämmigt tillsammans, har etablerade medlemmar och leds av en dirigent/körledare. En kör övar inför uppträdanden, har en på förhand vald repertoar och ljudet åstadkoms av en harmoni av röster. Definitionen fungerar i Nenolas fall men är ganska bred, vilket gör att den inrymmer allt från barnkör till i stort sett professionella symfonikörer. Det är en ganska stor skillnad på en liten församlingskör utan egna utgifter och till exempel Semmarit som drar fulla hus runtom i Finland med därav följande administration. Definitionen gör också att diskussionen om dam- och manskörernas respektive roller får en undanskymd roll. Avhandlingen går inte in på att körsången numera har feminiserats. Idag har många blandade körer svårt att rekrytera män (Kronqvist 2014). Däremot sjunger män gärna i manskörer, något som Nenola nämner men inte vidareutvecklar speciellt mycket. Följdfrågan blir varför män föredrar att sjunga med andra män. Här kunde begreppet homosocialitet använts som analytisk ingång. Inte heller traditionella körer med veckoövningar i relation till projekt-körer behandlas. Här kunde en stramare avgränsning ha varit att föredra, kanske till och med så att hon skulle ha fokuserat specifikt på några få exempelkörer eller till och med en kör, och relaterat dessa/denna till ett bredare körfält. Samtidigt förstår jag Nenolas önskan om att ha ett helhetsgrepp över fältet.

Eftersom etnografin är central i avhandlingen är det av central betydelse hur det etnografiska materialet är skapat. Det etnografiska materialet består av frågelistor, intervjuer och deltagande observation. Frågelistorna är tre till antalet där en är allmän, en fokuserar på ritualer i körsammanhang och en tredje på platsens betydelse. Totalt omfattar frågelistmaterialet över 100 svar. Intervjuerna är fem till antalet. Den deltagande observationen om 10 körers verksamhet gjordes under tre års tid. Materialet är således relativt stort. Enkäterna förmedlades via körledarna till respektive körs medlemmar men Nenola använde sig också av egna kontaktnät. Den största gruppen svarare är 51-64-åriga kvinnor vilket antagligen motsvarar körverkligheten i Finland ganska bra. Intervjupersonerna är handplockade och representerar sångare ur olika typer av körer. Trots att materialet är ganska omfattande, upplever jag att bilden, som analysen av det finländska körfältet ger, är aningen begränsad. Här framstår i många fall en liten damkör eller församlingskör som den "modellkör" Nenola medvetet eller omedvetet utgår ifrån. Det här kan bero på min egen bias som körsångare, och på att det finlandssvenska körfältet, som jag främst känner till, framstår som i viss grad 
annorlunda. Eventuellt kunde detta problem gällande representation ha lösts med ett större antal intervjuer, eller genom uttalat fokus endast på denna typ av körer.

\section{Tid-rum i körsångarens vardag}

Teoretiskt ligger fokus på performansteori, och specifikt Richard Schechners (2013) användning av begreppet med tonvikt på teaterföreställningens relation till ritualer. Nenola tangerar också det närliggande begrepp performativitet, som innebär ett fokus på ett (upprepat) görande. I sin analys lyfter hon speciellt fram Schechners begrepp upprepat beteende (restored behavior) och sekvenser av tid-rum. Avhandlingen är uppbyggd kring just denna tid-rum-sekvens. Den första består av förberedelser (proto-performance) och här presenteras körsjungandet med fokus på hur en körövning går till. Den andra delen består av själva performansen med alla ingredienser som ett körframträdande består av, allt från uppvärmning, själva framförandet och nedvarvningen efter framförandet. Den tredje tid-rum-sekvensen är mottagandet av framförandet, kritiken, minnet och upprepningen av den. Dessutom finns ett kapitel om performansen av körgemenskap och ett sammanfattande kapitel om körmusikens betydelser. På så sätt följer presentationen av analysen och det valda teoretiska greppet varandra på ett ändamålsenligt sätt.

Nenolas resultat visar att körsången förändrats under årens lopp och reflekterar många bilder av finländskhet under årens lopp. Körsången fungerar avstressande och ger möjlighet att känna gemenskap, samtidigt som Nenolas etnografi övertygande visar hur körsången förstärker självförtroendet och ger glädje. För en körsångare är det gemensamma musicerandet viktigast men det innebär inte att samvaron är betydelselös. Kören är också en plats där en individs status och yrkesmässiga bakgrund inte spelar någon roll. I analysen kommenteras begreppen communitas, gemenskapens betydelse, flow - när musiken flödar på ett sätt som gör att allt annat ter sig betydelselöst. Med hjälp av begreppet ritual visar Nenola hur rituella drag framkommer dels i visuella uttryck såsom kördräkter, sångarmärken och sångarfanor, dels ser hon körsjungandet som en ritual som lyfter en från vardagen. På så sätt är köraktiviteten ett liminalt tillstånd - en annorlunda tid i relation till vardagen.

Avhandlingen ger den icke-insatta värdefull kunskap om körsångarens vardag och också en förståelse för varför så många avsätter sina lediga kvällar och veckoslut på att sjunga i kör. För en körsångare som läser avhandlingen finns många glimtar av mycket välbekant men den ger också nya förståelser för körsången i det finska Finland.

\section{Litteratur}

Kronqvist, Hanna 2014. Körsång i Svenskfinland - en kartläggning. Helsingfors: Kulturfonden. https://www.kulturfonden.fi/wp-content/uploads/2016/01/koorerna.pdf

Schechner, Richard 2013. Performance studies. An introduction. Third ed. London: Routledge.

Lena Marander-Eklund är biträdande professor i nordisk folkloristik vid Åbo Akademi. 